\title{
Typification of some names in Eucalyptus (Myrtaceae), Part 3
}

\author{
A.R. Bean \\ Queensland Herbarium, Brisbane Botanic Gardens, Mt Coot-tha Road, Toowong, Queensland \\ 4066, Australia. \\ Email: tony.bean@derm.qld.gov.au
}

\begin{abstract}
Twelve names in Eucalyptus are here lectotypified, and the typification is clarified for a further three names. The species involved are indigenous to eastern Australia. Full discussion of relevant type specimens is given, and other nomenclatural notes are included.
\end{abstract}

\section{Introduction}

The first and second papers in this series (Bean 2009; Bean, in press) dealt with the typification of 29 current names in Eucalyptus. This paper deals with a further 15 current names, viz. E. abergiana, E. aggregata, E. amplifolia, E. baileyana, E. brevifolia, E. coccifera, E. consideniana, E. elata, E. fraxinoides, E. globulus var. pseudoglobulus, E. gunnii, E. johnstonii, E. pellita, E. perriniana and E. urnigera. 12 names are lectotypified, while for three names the typification is clarified or corrected. The species treated herein are indigenous to eastern Australia, and have been chosen after detailed examination of the nomenclature information in the protologue and in subsequent publications.

These typifications are necessary to provide a unique type specimen for each name, thereby fixing the application of the name. Nomenclatural information offered by Chippendale (1988), Hill and Johnson (1998), Hill (2002-04) and Slee et al. (2006) is discussed, especially where it differs from the view expressed here.

The species are arranged alphabetically by the basionym.

\section{Typification}

Eucalyptus abergiana F.Muell., Fragm. 11:41 (1878) [= Corymbia abergiana (F.Muell.) K.D.Hill \& L.A.S.Johnson, Telopea 6: 244 (1995)].

Type citation: "In vicinia sinus Rockingham's Bay ad montes; Dallachy". Lectotype (Chippendale 1988, p. 97): Queensland. Rockingham Bay, J. Dallachy 21, 24 March 1867 (MEL1616369; isolecto: NSW306297).

Specimens collected from Rockingham Bay by John Dallachy are present at MEL, NSW 
and K, with two sheets at each of these herbaria. These sheets are from at least two gatherings. One of the sheets at NSW (NSW306298) has a label written by Dallachy with the date 1 August 1867. One of the sheets at MEL also has an original Dallachy label, but with the date 24 March 1867, while the second sheet (MEL1616368) is undated.

Chippendale (1988) cited the type as "T: Rockingham Bay, Qld, 24 Mar. 1867, J. Dallachy 21; holo: MEL; iso: K, NSW.” In so doing, he has effectively lectotypified the name using the sheet at MEL with this date (MEL1616369). Dallachy's label includes the number " 21 " in his handwriting, seemingly a collection number. NSW306297 also includes the number 21 , and so this sheet can reasonably be designated as an isolectotype. It is not possible to firmly link either of the specimens at $\mathrm{K}$ to the lectotype, either from the plant material present, or from details on the labels, and so these should not be regarded as isolectotypes.

Eucalyptus aggregata H.Deane \& Maiden, Proc. Linn. Soc. New South Wales 24(4): 614 (1900).

Type citation: "Wallerawang (H.D.); Rydal (J.H.M.); Jenolan Caves (W. Blakely); near Orange, on the Cadia-road, which remains its most western locality at present (R.H. Cambage); Rockley and Burraga (R.H.C.). It has not been recorded north of Sydney, and its southern localities are Nimbo Station, head of the Queanbeyan River; also Crookwell (H.D.) and Fagan's Creek, Braidwood district (Mr. W. Bäuerlen, communicated by Mr. R.T. Baker).” Lectotype (here designated): New South Wales. Wallerawang, H. Deane s.n., October 1886 (NSW313030; isolecto NSW313029).

The initials "H.D." mentioned in the type citation refer to Henry Deane. Maiden (1915: $100)$ stated in a figure caption " $7 a$. Small juvenile leaves; $7 b$, fruits. Wallerawang, N.S.W. (J.H.M.) Both from the type.” Chippendale (1988) accepted this as a lectotypification of the name. However, Maiden's statement does not validly lectotypify the name because the Wallerawang specimen cited in the protologue was collected by Henry Deane, not by J.H. Maiden. It does however indicate that Maiden considered Wallerawang to be the type locality. To validate his concept, a sheet collected by H. Deane from Wallerawang (NSW313030) is here chosen as the lectotype. The specimen matches the protologue and is of good quality. It comprises pressed unmounted branchlets bearing adult leaves, flower buds and mature fruits. A second sheet of lesser quality from the same gathering (NSW313029) is an isolectotype.

Eucalyptus amplifolia Naudin, Descr. Emploi Eucalyptus introd. Europe, $2^{\text {nd }}$ Memoire 28 (1891).

Type citation: "Je l'ai trouve dans plusiers endroits de l'Algerie, dans nos jardins de Provence, dans celui de M. Hanbury, a la Mortola, pres de Menton; j'en ai recu des echantillons de M. Ricasoli, de Florence et nous en possedens plusiers exemplaires de differents ages a la villa Thuret”. Lectotype (here designated): Algeria. Bois du Bologne, C. Naudin s.n., undated (P, 1st sheet cited below; isolecto: P, $2^{\text {nd }}$ sheet cited below).

The lectotype is mounted on two sheets, and comprises four mounted branchlets with adult leaves and mature fruits. The first sheet bears a label in Naudin's handwriting saying "Eucalyptus amplifolia Ndn./ du Bois de Boulogne d'Alger, administration forestière/ Ch. Ndn.", and a determinavit slip by J.H. Maiden with the name "Euc. tereticornis, Sm. var. latifolia", dated May 1903. It is also stamped "Reçu en Mars 1890", confirming that the material was collected before publication of the name. The label of the second sheet says "Eucalyptus amplifolia Naud./ Bois de Boulogne [...] Alger/ 


\section{Ch. Naudin".}

Eucalyptus baileyana F.Muell., Fragm. 11: 37 (1881).

Type citation: "Ad sinum marinum Moreton-Bay rara; Bailey”. Lectotype (Chippendale 1988, p. 117): Queensland. Coopers Plain, F.M Bailey s.n., June 1878 (MEL1606591, possibly holo).

There are two relevant sheets at MEL that were collected by F.M. Bailey. MEL1606591 comprises some mounted branchlets bearing adult leaves, two mature fruits attached to a leafless branchlet, and some strips of bark and wood. This sheet is in accord with the protologue and is original material. Accompanying this sheet is a letter from Bailey to Mueller saying that he considered this to be a new species, and giving details on its morphology and supposed affinities. Bailey also stated that "the flowers are not out as yet ...".

The second sheet (MEL1607734) bears some fruits in a packet, some of which have been cut in transverse section. This sheet bears two labels written by Bailey. One of these states (in part) "Eucalyptus Baileyana FvM/ In Fragmt 89 you say that you have not seen the seed...”. Bailey has cited the published name and has clearly seen the issue of Fragmenta in which it was published. Hence MEL1607734 post-dates the publication of the name and is not original material.

Chippendale (1988) cited “T: near Moreton Bay, Qld, Jun 1878, F.M.Bailey s.n.; holo: MEL; iso: NSW." This constitutes a valid lectotypification as the date is sufficient to specify the sheet at MEL to which he was referring. Under Article 9.8 (McNeill et al. 2006), his use of the term "holotype" is correctable to "lectotype". Hill (2002-04) cited the type in that way, i.e. (lecto: MEL, isolecto NSW, BRI, K).

Hill \& Johnson (1998: 408) cited “Type: Qld. near Moreton Bay, F.M. Bailey s.n., 1869 (holo: MEL; iso: NSW, BRI, K)". The material at NSW is a mixture of two species, and is distributed on two sheets. The fruits on these sheets belong to E. baileyana as described in the protologue, but the leaves, buds and flowers belong to E. tindaliae Blakely. The fruits could be part of the original gathering by Bailey, as they are similarly attached to a leafless branchlet, but it is impossible to say. The non-fruiting material is not original material as it bears open flowers. Mueller stated in the protologue that he had not seen flowers, with the words "flores statu evoluto nondum me visi".

There are two sheets at $\mathrm{K}$ that bear material remarkably similar to that at NSW i.e. fruits of E. baileyana attached to leafless branchlets, and flowers buds and leaves of E. tindaliae (although identified by M.I. Brooker as 'E. ?laevopinea').

The specimen at BRI considered by Hill and Johnson (1998) to be a type is probably AQ 055285. It was collected from "Eight Mile Plains" and is obviously an old specimen, and has been marked as a "Co-type" in the handwriting of C.T. White. There is no writing by Bailey on the label and indeed no evidence that it could be original material. It is here concluded that the material at NSW, K, and BRI should not be considered isolectotypes.

The lectotype (MEL1606591) is the only indisputable extant type material that is known for E. baileyana.

Eucalyptus brevifolia F.Muell., J. Proc. Linn. Soc., Bot. 3: 84 (1859).

Type citation: "In eremis terrae tabularis ad flumina Victoria et Sturt's Creek, in plaga 
Arnheim's Land et circum sinum Carpentaria." Type: "Victoria R., stony ridges, May 1856, F. Mueller (K, MEL, BRI)", fide Blake (1953), p. 272. Lectotype (here designated): Northern Territory. Victoria River, stony ridges, F. Mueller s.n., May 1856 (K000279690; isolecto: BRI [AQ103085], MEL231974).

Blake (1953) gave a comprehensive discussion on the nomenclature of E. brevifolia and E. pallidifolia F.Muell., showing that both of these names are applicable to the same species. He typified E. brevifolia, but cited specimens from three herbaria. Under the provisions of Art. 9.15 (McNeill et al. 2006), the initial lectotypification of Blake (1953) is here narrowed to the $\mathrm{K}$ specimen, as it is of much better quality than the material at MEL and BRI. The MEL and BRI specimens become isolectotypes.

The lectotype is of good quality and has two pressed and mounted branchlets, one bearing adult leaves and numerous mature fruits, and the other bearing adult leaves and immature buds. There are also a few fruits mounted separately in the corner of the sheet.

Eucalyptus coccifera Hook.f., London J. Bot. 6: 477 (1847).

Type citation: "Hab. Tops of mountains: Lawrence, Gunn." Lectotype (here designated): Tasmania. Mt Wellington, R.C. Gunn 1076, 30 October 1840 (K000347508; isolecto NSW334881).

There are specimens mounted on four sheets at $\mathrm{K}$ that can confidently be considered original material. On one sheet is a collection by R.W. Lawrence, and material on the other three sheets was collected by R.C. Gunn. J.D. Hooker added the epithet coccinellifer to the label of Lawrence's specimen, obviously inspired by his mention of "a species of Coccus" that grew on the tree. Hooker later amended the epithet to coccifera.

The specimen chosen as lectotype consists of two pressed and mounted branchlets, one bearing adult leaves and mature fruits; the other bearing adult leaves and flower buds. The buds are apparently close to maturity, but no open flowers are evident. There is no reason to suspect that these two branchlets are not part of the same gathering. The lectotype matches the description in the protologue. The other Gunn collections of E. coccifera are not isolectotypes because the collection dates are different. NSW334881 has an original Gunn label with details exactly matching the lectotype, hence it is an isolectotype.

Eucalyptus consideniana Maiden, Proc. Linn. Soc. New South Wales 29: 475 (1904).

Type citation: "Mr Deane and I first collected it near Springwood in 1888. I have received it during the last four or five years from the following localities - Pigeon House Mountain, near Milton; grows to within 100 feet of the top, on sandy, rather barren soil; also sandy ground at Burrill, Ulladulla (R.H. Cambage); Wingello (J.H. Boorman); top of mountain east of Burragorang (R.H. Cambage); Penang Mountain (A. Murphy)." Lectotype (here designated): New South Wales. top of mountain east of Burragorang, R.H. Cambage 1022, 11 November 1901 (NSW335808).

Most of the specimens that match the type citation are extant at NSW. Maiden (1908) cited in a figure caption " $3 c$. fruits of type. Pigeon House, Milton, N.S.W. (R.H. Cambage)". This does not constitute a valid lectotypification, because there are two gatherings (December 1899 and 31 December 1902) at NSW matching this citation.

A specimen at NSW collected from east of Burragorang by Cambage, and cited in the 
protologue is chosen here as the lectotype. It is a very good quality specimen and is in full accord with the description given in the protologue. It comprises a pressed unmounted branchlet bearing adult leaves, mature buds, flowers and mature fruits. The material of the lectotype is more complete and diagnostic than that of other specimens cited in the protologue, including the two gatherings from Pigeon House.

Eucalyptus elata Dehnh., Cat. Horti Camald. 26 (1829).

Type citation: "colitur in Horto Camaldulensi". Lectotype (here designated): [Italy]. ex Hortus Camalduli, F. Dehnhardt s.n., undated (RO; isolecto: NAP).

German gardener and botanist Freidrich Dehnhardt described this species in 1829, based on a cultivated plant grown in the garden of the Duke of Camalduli's estate near Naples in Italy.

The protologue provides a detailed description, including "bark smooth ... branches hanging down ... operculum hemispherical, mucronulate ... lower leaves opposite, sub-sessile ... flowers very numerous, crowded, umbellate, umbels axillary". No specimens were cited in the protologue. A prolonged search for original material has revealed relevant specimens at RO, NAP and W. High quality images of all specimens have been examined by the present author. In the case of $\mathrm{W}$, the digital herbarium was used (Anon. 2006+).

The single specimen at RO bears two old labels. One reads "Eucalyptus elata Dehnt/ ab ipso auctore", in the handwriting of V. Cesati (according to Agostini (1958)). Cesati's notation indicated the second label which, in Dehnhardt's handwriting, reads "E. elata D.", under which someone else has written "Dehnhardt! Ex H. Camaldul.” The second label confirms the origin of the specimen as the garden of the Duke of Camalduli's estate near Naples. This specimen comprises three mounted branchlets bearing mature leaves, clusters of mature buds, and open flowers. This specimen is here selected as the lectotype.

The two specimens at NAP are unmounted and each has two labels, one in the handwriting of Dehnhardt and one written by G. Gussone (according to Agostini (1958)). The first specimen comprises a single branchlet bearing adult leaves, mature buds and open flowers, and is so similar to the lectotype that it is very likely part of the same gathering. The label includes the notation "cult. Camal." Unfortunately this specimen has been severely damaged by insects. The second specimen comprises juvenile leaves and two detached umbels of buds close to maturity. The label mentions the locality of "Portico" which is close to Naples.

There are Eucalyptus specimens on six sheets at $\mathrm{W}$ that are labelled as being from the Hortus Camaldulensis or Naples and are attributed to Dehnhardt. Two of these sheets (W21344, W21346) do not match the protologue, and belong to another species. One sheet (W21347) bearing mature fruits is at odds with the protologue because fruits are not mentioned. The other three sheets (W21342, W21343, W21345) could all be original material. These specimens comprise mounted branchlets with adult leaves, sessile to subsessile intermediate leaves and immature buds. On the original label for W21342 and W21343 is written "C.h.V. e [...] neapol. a Dehnhardt" by a person unknown, while the original label for W21345 has "Eucalyptus elat" in Dehnhardt's handwriting, under which someone else has written "Hort. Camaldul. Dehnhardt". While these three W specimens are probably original material, they are clearly from a 
different gathering when compared to the material preserved at RO and NAP, because of the presence of sessile to subsessile intermediate leaves on the fertile branchlets and immature flower buds only.

The RO specimen is here chosen as the lectotype for the name as it is of very good quality, it matches the protologue, and it has a label stating "E. elata D." in Dehnhardt's handwriting. The first mentioned specimen at NAP is considered an isolectotype.

Eucalyptus fraxinoides H.Deane \& Maiden, Proc. Linn. Soc. New South Wales 23: 412 (1898); E. virgata var. fraxinoides (H.Deane \& Maiden) Maiden, Forest Fl. New South Wales 3: 87 (1907).

Type citation: "On high mountain ranges of the extreme southern part of New South Wales. Herbarium specimens collected by W. Bäuerlen and the authors on Tantawangalo Mountain (3,000 feet) near Cathcart". Lectotype (Maiden (1920), p. 299): New South Wales. Tantawanglo Mountain, H. Deane \& J.H. Maiden s.n., December 1896 (NSW26878).

The protologue mentions specimens collected by Deane and/or Maiden, and also specimens collected by William Baeuerlen. Three relevant specimens are present at NSW and one at BM.

Maiden (1920) stated “Tantawanglo Mountain (Henry Deane and J.H.M., 1896). The type." This statement constitutes a valid lectotypification. There is only one specimen matching the protologue that was collected by Deane and Maiden in 1896, namely NSW26878.

The lectotype comprises pressed unmounted branchlets bearing adult leaves, very immature flower buds and mature fruits, and there is also a strip of bark.

Chippendale (1988) failed to recognise the lectotypification by Maiden, and recorded three syntypes for this name. This was followed by Slee et al. (2006) and Nicolle (2006).

Eucalyptus globulus var. pseudoglobulus Naudin, Descr. Emploi Eucalyptus introd. Europe, $2^{\text {nd }}$ Memoire 34 (1891); E. pseudoglobulus (Naudin) Maiden, Crit. Revis. Eucalyptus 8: 28 (1929); E. globulus subsp. pseudoglobulus (Naudin) J.B.Kirkp., J. Linn. Soc., Bot. 69: 101 (1975).

Lectotype (here designated): France. Villa Thuret, Naudin s.n., undated (P).

In a treatment of Eucalyptus globulus, Naudin (1891) included the following paragraph: “Nous ne lui connaissons jusqu'ici qu'une seule variété, celle qui a reçu le nom de pseudoglobulus, qui ne se distingue du globulus ordinaire que par le volume de ses fruits, de trois ou quatre fois plus petits que ceux du type commun. Il y a d'ailleurs tous les passages entre les extremes de volume". This constitutes valid publication of the name E. globulus var. pseudoglobulus by Naudin, because he made a morphological distinction between it and the typical form, and he specified varietal rank.

Naudin did not cite any specimens in the protologue. Chippendale (1974) referred to four specimens that he photographed at $\mathrm{P}$, and which he considered were original material. The present author has examined these photographs, and has chosen a lectotype from them. The chosen specimen comprises a single sheet with a mounted branchlet bearing adult leaves and several clusters of mature fruits. The label of this specimen is in the handwriting of Charles Naudin and reads "Eucalyptus globulus Labill. var. pseudo-globulus, [...] microcarpa/ fruits 5 à 6 fois plus petits qui dans 
les variétés à gros fruits/ Villa Thuret/ Ch. Ndn.” A printed “Herb. Mus. Paris” label states that the specimen was received from Charles Naudin in 1890. This specimen was photographed by G. Chippendale in 1973, and the Negative number 686 appears in the top-left corner of the photo.

Maiden (1929) recognised E. pseudoglobulus at species rank, and attributed Naudin as its author. The correct author citation is "(Naudin) Maiden", as Maiden effectively raised Naudin's variety to species rank.

Kirkpatrick (1975) described E. globulus subsp.pseudoglobulus. He designated "Metung, 23 August 1909, J.L. King s.n. (NSW)" as the lectotype. The basionym of this name is E. globulus var. pseudoglobulus Naudin, published in 1891. Kirkpatrick's choice of lectotype is invalid, as it is not original material.

Eucalyptus gunnii Hook.f., London J. Bot. 3: 499 (1844).

Type citation: "on the elevated tablelands of the interior of Tasmania, especially in the neighbourhood of the lakes (Gunn. n. 1084, 1080, 1082)". Lectotype (here designated): Tasmania. Lake Arthur, R. Gunn 1084/1842, 18 February 1843 (K000279739; isolecto: NSW314848, possible isolecto: BM).

At $\mathrm{K}$, there is plant material collected by Gunn and mounted on five sheets, and probably all of this material was available to Hooker when drawing up his description.

Gunn's "collection" numbers are in fact taxon numbers, i.e. he gave a constant number to every species he recognised (Haegi 1982; Buchanan 1988). While all of the material on the five sheets belongs to the same currently recognised taxon, Gunn evidently recognised differences within it, and used the numbers 1080, 1082, and 1084 for them. Clearly then, Gunn's ' 1080 ' would have been from a different tree to his ' 1084 ' or ' 1082 ' and hence a separate gathering. It is difficult to know how many gatherings were involved, but the minimum is five, involving various combinations of the dates '18/2/43', '18/2/42' and 'March 1840', and taxon numbers '1080', '1082' and '1084' written by Gunn on various labels.

The protologue includes descriptions of buds, flowers and fruits, hence it is not possible to exclude any specimen because it bears a structure not mentioned in the protologue. A specimen with an original Gunn label from Lake Arthur has been chosen as the lectotype ("lakes" are mentioned in the protologue). It comprises a single branchlet with adult leaves, mature buds and open flowers. This branchlet has the accession number K000279739 separate from other material mounted on the same sheet.

NSW314848 has an original Gunn label with details matching the lectotype. From the locations and dates provided by Chippendale (1974) for E. gunnii material present at $\mathrm{BM}$, it is likely that some of the BM material is of the same gathering as the lectotype, and could be reliably designated as isolectotype.

Eucalyptus johnstonii Maiden, Crit. revis. Eucalyptus 6: 280 (1922); E. muelleri T.B.Moore, Pap. \& Proc. Roy. Soc. Tasmania for 1886: 207 (1887), nom. illeg. non Miq. (1856).

Type citation: "on a saddle of the dividing range between the Huon and Derwent watersheds”. Lectotype (here designated): Tasmania. Mt Wellington, 2000' and lower, T.B. Moore s.n., anno 1886 (MEL1610541; isolecto: MEL1610560).

There are two specimens at MEL collected by Moore and matching the protologue. 
In a letter to Ferdinand von Mueller, Moore said that "The tree was first met with on a saddle of the Mt Wellington range, due north and south from the two townships [New Norfolk and Victoria]". However in the protologue, he did not use the term "Mt Wellington range", but merely wrote "dividing range". This explains the discrepancy between the type citation and the label of the lectotype.

The lectotype consists of two pressed and mounted branchlets, one bearing adult leaves and mature fruits; the other bearing adult leaves and flower buds. The buds are apparently close to maturity, but no open flowers are evident. The lectotype matches the description in the protologue. The isolectotype bears only adult leaves and flower buds.

Eucalyptus pellita F.Muell., Fragm. 4: 159 (1864); E. resinifera var. pellita (F.Muell.) F.M.Bailey, Syn. Queensl. Fl. 179 (1883).

Type citation: "Ad sinum oceanicum Rockingham Bay. Dallachy." Lectotype (here designated): Queensland. Rockingham Bay, J. Dallachy 128, 5 June 1864 (MEL1611097; isolecto: MEL1611096, probable isolecto: K000279538).

The date of publication for Eucalyptus pellita was November 1864 (Chapman 1991). Mueller, in the protologue did not describe flower buds, and he stated that he had not seen flowers.

There are four sheets at MEL collected by John Dallachy that have been annotated as type material by previous workers. One of these (MEL1611094) can be excluded because it was collected after the publication date, and another (MEL231894) can be excluded because it bears mature flower buds.

The remaining two sheets at MEL are considered to be part of the same gathering. MEL1611097 has branchlets with adult leaves, and a single fruit in a fragment packet. It has a label in Dallachy's hand that reads as follows: "June 5 June 1864/ A beautiful gum 40 to 50 feet high/ bark rough dark grey/ wood very hard red in centre/ foliage dark green/ no flowers/ the tree was cut down to make a new pole for the dray/ 128". Below that, written in Mueller's hand is "Eucalyptus pellita FvM". This sheet is here designated as the lectotype. MEL1611096 bears branchlets with adult leaves and a cluster of mature fruits, while the label says "Rockingham Bay" in Mueller's hand. It is an isolectotype.

A sheet at K (K000279538) has leaves similar to the lectotype and fruit of the same size and stage of maturity, and it is probably an isolectotype. Another sheet at $\mathrm{K}$ (K000279539), also collected by Dallachy, bears mature buds and flowers. Therefore it is not original material.

Eucalyptus perriniana Rodway, Pap. \& Proc. Roy. Soc. Tasmania for 1893: 181 (1894).

Lectotype (here designated): Tasmania, north of Hamilton, L. Rodway s.n., May 1892 (HO 16178).

The protologue states "It is a eucalypt that has long been known in the Hamilton... district", and "the kindness of Rev. Mr. Dicker and Superintendent Hedberg has placed at my disposal various specimens at different stages".

There is no original material of E. perriniana at K or BM (Chippendale 1974; J. Bruhl, pers. comm.). However, there are two specimens at MEL and one at HO that mention "Hamilton" as the locality and predate the publication of the name. Leonard Rodway is attributed as the collector for all of these specimens. There are no relevant specimens 
attributed to Hedberg or Dicker in any of the herbaria mentioned.

MEL1611947 has mounted branchlets bearing sessile connate leaves and petiolate leaves with a few fruits attached, and there is a fragment packet containing numerous detached fruits and leaves. An accompanying letter from Rodway to Mueller is dated "Oct 1/ 92". MEL1611948 has two mounted branchlets, one bearing sessile connate leaves and the other bearing petiolate leaves with spent flowers. The accompanying letter from Rodway to Mueller is dated "Apr 27 / 92". HO16178 bears pressed and mounted branchlets of both connate juvenile and petiolate adult foliage, the latter with fruits attached. There is also a fragment packet containing some fruits and two spent flowers. The HO specimen is here chosen as the lectotype. Judging by the dates on the MEL specimens, neither is an isolectotype.

R.L. Rodway gave the first description of the species in 1894. Baker \& Smith (1913) redescribed E. perriniana in more detail, and claimed authorship for themselves. Rodway's description is rather informal, but is certainly sufficient for valid publication of the name, hence the naming by Baker \& Smith is superfluous and illegitimate.

An alternative authorship for E. perriniana is "F.Muell. ex Rodway". In the protologue, Rodway mentioned that Mueller had given it the epithet of 'perriniana'.

Eucalyptus urnigera Hook.f., London J. Bot. 6: 477 (1847).

Type citation: "Hab. Mt Wellington and Lake Echo; Gunn." Lectotype (here designated): Tasmania. Mt Wellington, R.C. Gunn 1074/1842, 9 February 1839 (K000279742; isolecto: BM000796087, NSW313892, NSW313894).

There are six sheets at $\mathrm{K}$ that have been attributed to Gunn, and were collected at either Mt Wellington or Lake Echo. All of these are original material.

Gunn's collection numbers are actually species numbers, and these are sometimes associated with a year (in this case 1842), this being the year of shipment (Buchanan 1988).

The lectotype consists of four pressed branchlets mounted on one sheet, bearing adult leaves with either mature fruits or flower buds. The buds are apparently close to maturity. Two open flowers attached to a peduncle, but unattached to any branchlet, are mounted separately. There is no reason to suspect that all of this material is not part of the same gathering. The lectotype has an original Gunn label with the location, date and collecting number, and the specimen matches the description in the protologue. The isolectotype at BM has the label "1074/ Mt Wellington" in Gunn's handwriting. It comprises two pressed and mounted branchlets bearing adult leaves, buds and flowers.

\section{Acknowledgments}

I am grateful to the Directors of the National Herbarium of Victoria (MEL) and the National Herbarium of New South Wales (NSW), for allowing my access to their eucalypt collections, and for assistance during my visits; Jeremy Bruhl (Australian Botanical Liaison Officer at K, 2008-09) for sending images of eucalypt types or potential types; Brendan Lepschi (CANB) for sending on loan type photographs held at that herbarium. I acknowledge the Board of Trustees, Royal Botanic Gardens, Kew, and the Natural History Museum London (BM) for allowing specimen images to be supplied to me. My sincere thanks to Dr Roberta Vallariello (NAP) and Anna Millozza (RO) 
for photographing the specimens and labels of E. elata types held at their institutions. Gillian Perry cheerfully answered my many nomenclatural queries. Thanks to Alex Buchanan (HO) for his willing assistance with type material of E. perriniana, Val Stajsic for supplying information about specimens held at MEL, and to Wayne Gebert and Catherine Gallagher for sending images of some specimens held at MEL.

\section{References}

Agostini R (1958) Considerazioni sulla sinonimia di Eucalyptus elata Dehnh. (1829) con Eucalyptus Lindleyana DC. (1828). Delpinoa; Nuova Serie del Bulletino dell' Orto Botanico della Universita di Napoli 11: 223-241.

Anon. (2006+) Virtual Herbarium for GJO, GZU, HAL, JE, TGU, W and WU. http://herbarium. univie.ac.at/database/search.php Accessed 3 August 2009.

Baker RT \& Smith HG (1913) A research on the Eucalypts of Tasmania and their essential oils. Papers and Proceedings of the Royal Society of Tasmania for 1912: 139-209.

Bean AR (2009) Typification of some names in Eucalyptus (Myrtaceae), Part 1. Telopea 12(3): 309-319.

Bean AR (in press) Typification of some names in Eucalyptus (Myrtaceae), Part 2. Telopea 12(4).

Blake ST (1953) Studies on Northern Australian species of Eucalyptus. Australian Journal of Botany 1: 185-352.

Buchanan AM (1988) R.C. Gunn and J. Milligan; A cautionary note. Australian Systematic Botany Society Newsletter 54: 1-4.

Chapman AD (1991) Australian Plant Name Index, D-J. Australian Flora and Fauna Series 12. (Australian Biological Resources Study: Canberra).

Chippendale GM (1974) Herbarium specimens of Eucalyptus photographed in Europe. (Technical Note No. 7. Forestry and Timber Bureau: Canberra).

Chippendale GM (1988) Eucalyptus, Angophora (Myrtaceae). Flora of Australia 19. (Australian Government Publishing Service: Canberra).

Haegi L (1982) Some observations on Gunn's Herbarium of Tasmanian plants. Australian Systematic Botany Society Newsletter 32: 8-9.

Hill KD (2002-04) Eucalink, A web guide to the eucalypts. Royal Botanic Gardens, Sydney. Available at http://plantnet.rbgsyd.nsw.gov.au/PlantNet/Euc/index.html Accessed 12 June 2009.

Hill KD \& Johnson LAS (1998) Systematic studies in the eucalypts. 8. A systematic study of the Eudesmioid eucalypts, Eucalyptus subgenus Eudesmia (Myrtaceae). Telopea 7(4): 375-414.

Kirkpatrick (1975) The numerical infraspecific taxonomy of Eucalyptus globulus Labill. (Myrtaceae). Journal of the Linnean Society, Botany 69: 89-104.

Maiden JH (1908) Explanation of Plates (45-48). A Critical Revision of the Genus Eucalyptus. volume 1, part 10, pp. 345-348. (Government Printer: Sydney).

Maiden JH (1915) Eucalyptus aggregata. A Critical Revision of the Genus Eucalyptus. volume 3, part 25, pp. 85-87, 100 (Government Printer: Sydney).

Maiden JH (1920) Eucalyptus fraxinoides. A Critical Revision of the Genus Eucalyptus. volume 4, part 39, pp. 298-302. (Government Printer: Sydney).

Maiden JH (1929) Eucalyptus pseudoglobulus. A Critical Revision of the Genus Eucalyptus. volume 8, part 71, pp. 28-29. (Government Printer: Sydney).

McNeill J, Barrie FR, Burdet HM, Demoulin V, Hawksworth DL, Marhold K, Nicolson DH, Prado J, Silva PC, Skog JE, Wiersema JH \& Turland NJ (2006). International Code of Botanical Nomenclature (Vienna Code). (International Association for Plant Taxonomy: A.R.G. Gantner Verlag, Ruggell, Liechtenstein).

Naudin C (1891) Description et emploi des eucalyptus introduits en Europe, principalement en France et en Algérie et deuxième mémoire. (J. Marchant: Antibes).

Nicolle D (2006) Eucalypts of Victoria and Tasmania. (Bloomings Books: Melbourne).

Slee AV, Brooker MIH, Duffy SM \& West JG (2006) EUCLID, Eucalypts of Australia Third edition (DVD-ROM). (Centre for Plant Biodiversity Research, Canberra). 